NASZA DERMATOLOGIA Online OUR DERMATOLOGY Online

Source of Support:

Nil

Competing Interests

None

\section{EPONYMS IN THE DERMATOLOGY LITERATURE LINKED TO THE VASCULAR TUMORS}

\author{
Khalid Al Aboud ${ }^{1}$, Ahmad Al Aboud ${ }^{2}$ \\ ${ }^{1}$ Department of Public Health, King Faisal Hospital, Makkah, Saudi Arabia \\ ${ }^{2}$ Dermatology Department, King Abdullah Medical City, Makkah, Saudi Arabia
}

Corresponding author: Dr. Khalid Al Aboud

amoa65@hotmail.com
The term "eponym" originates from the Greek word "eponymous", which means "named after". Dermatology literature is rich in eponyms [1].

In this communication, we aimed to highlight on selected eponyms in dermatology literature linked to the vascular tumors, which we listed it in in Table I [1-7].

However, we want to stress that this table is by no mean conclusive as some eponyms linked to vascular lesions in the skin are not included.For examples; Campbell De Morgan spots (also known as senile angiomas or cherry angiomas), which is named after the nineteenth-century British surgeon Campbell De Morgan (1811-1876). Also Kasabach-Merritt syndrome, in which a vascular tumor leads to decreased platelet counts and sometimes other bleeding problems, It is named after Haig Haigouni Kasabach (1898-1943) and Katharine Krom Merritt (1886-1986), the two American pediatricians who first described the condition in 1940.

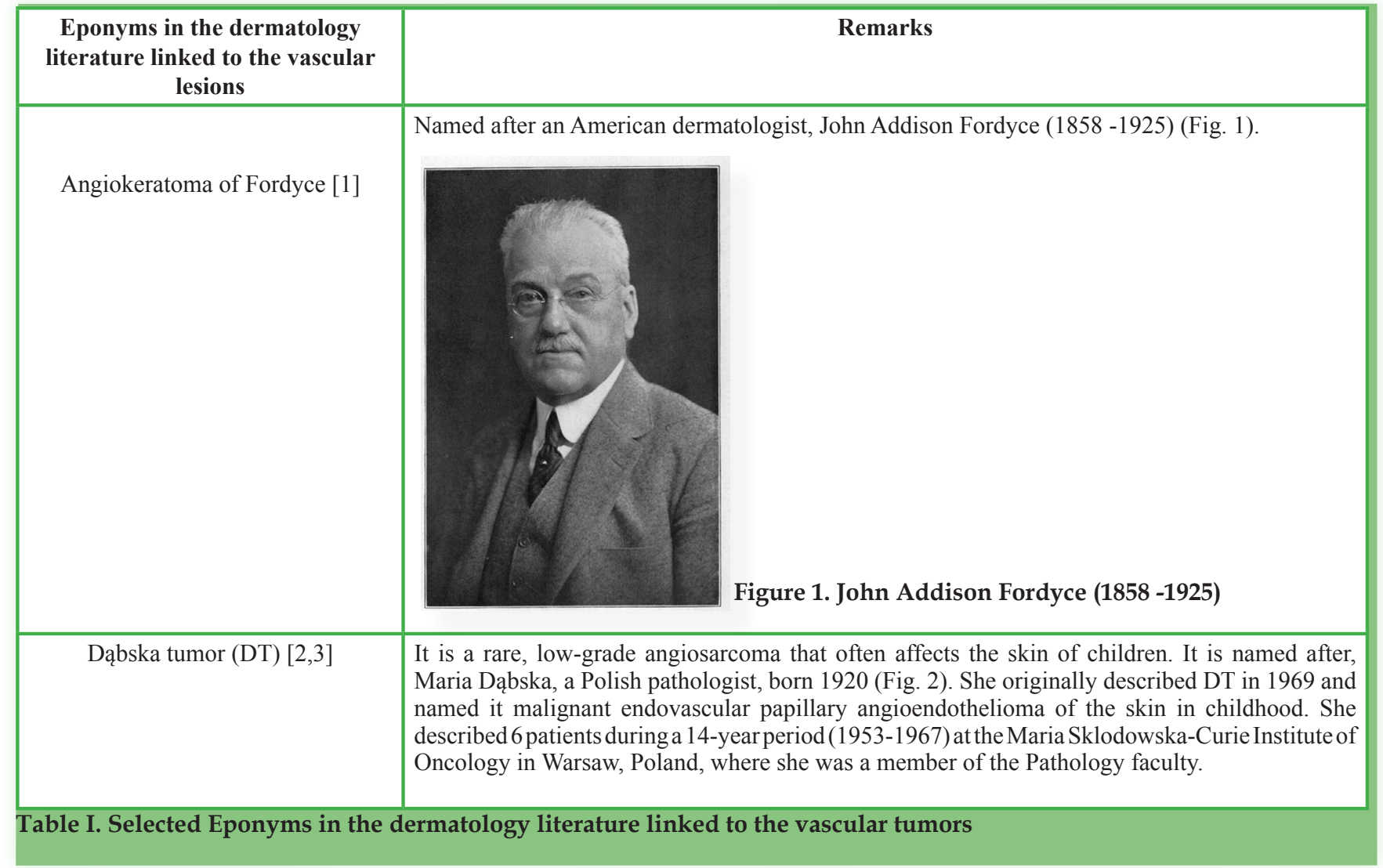




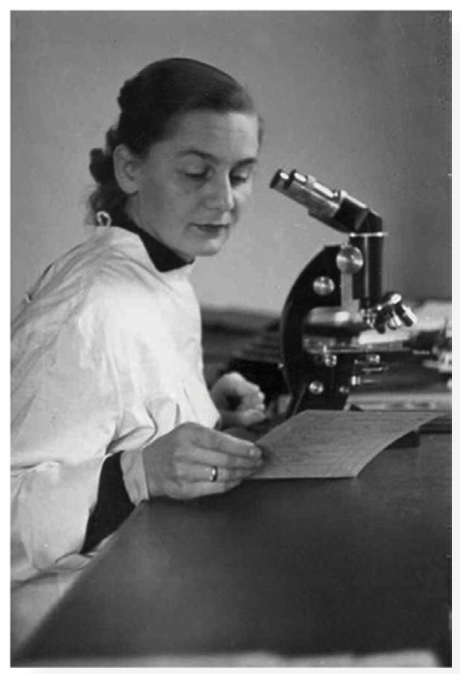

Figure 2. Maria Dąbska. Reproduced from reference number 3 .

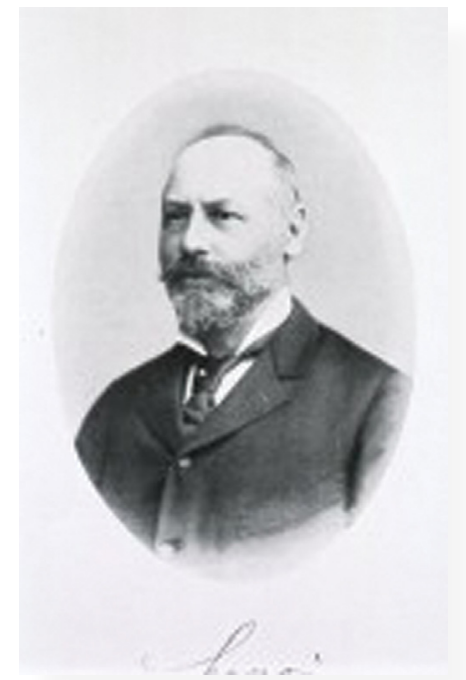

Figure 3. Moritz Kaposi (1837-1902). Reproduced from reference number 4 .

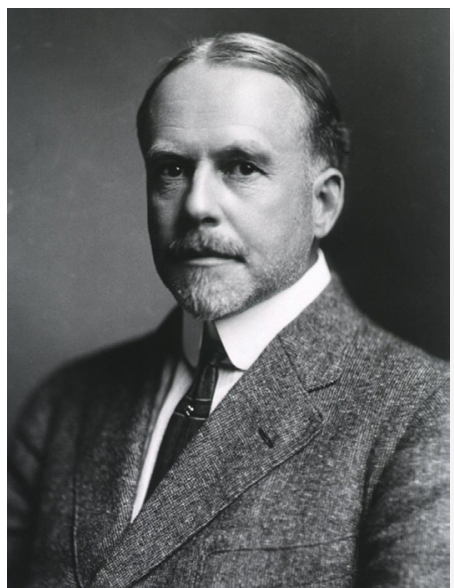

Figure 4. Aldred Scott Warthin (1866-1931). A courtesy of National library of Medicine.

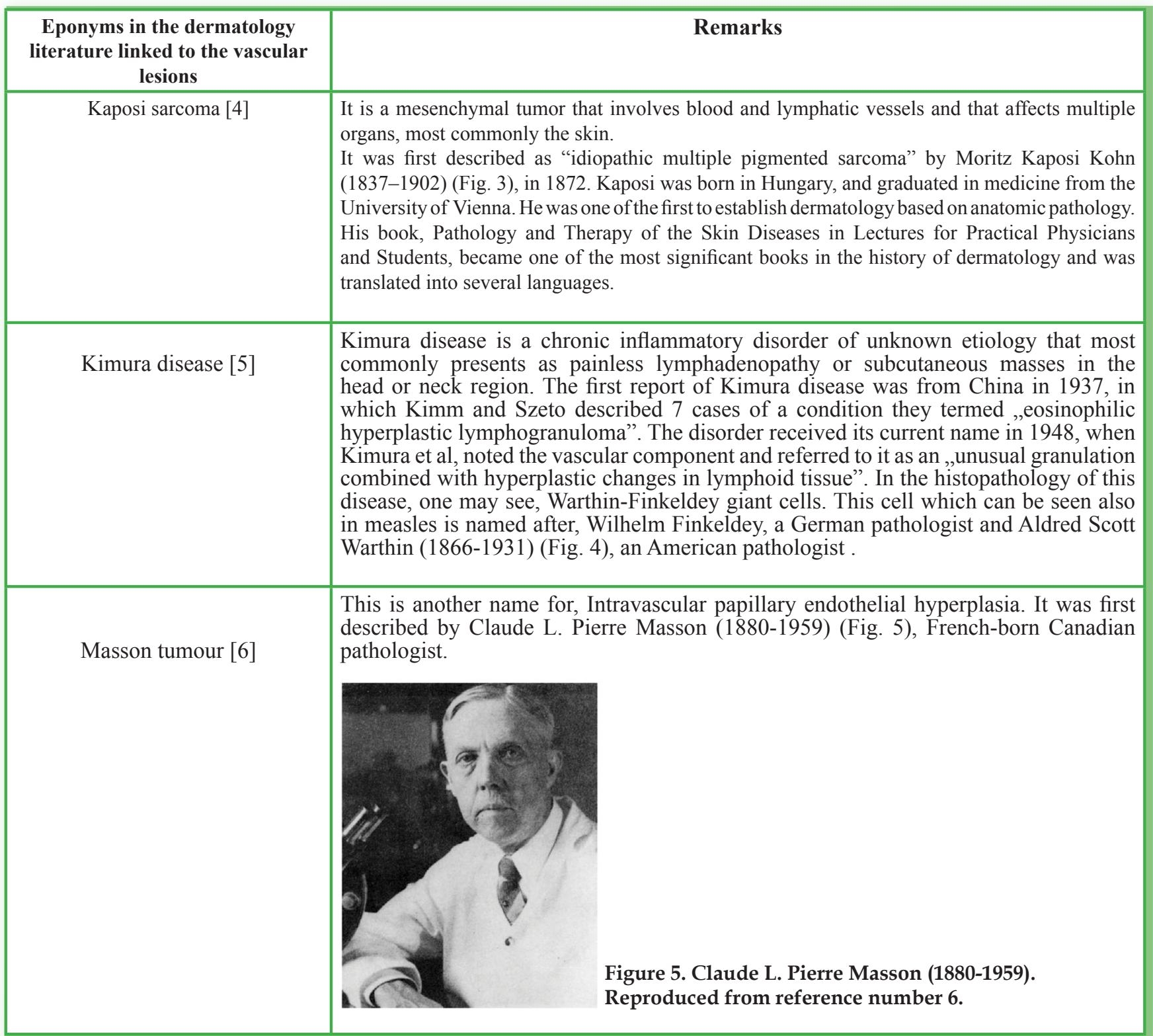

Table I. Selected Eponyms in the dermatology literature linked to the vascular tumors (continued) 


\begin{tabular}{|c|c|}
\hline $\begin{array}{c}\text { Eponyms in the dermatology } \\
\text { literature linked to the vascular } \\
\text { lesions }\end{array}$ & \multicolumn{1}{c|}{ Remarks } \\
\hline Sucquet-Hoyer canal [7] & $\begin{array}{l}\text { This is part of glomus body from which glomus tumor arise. Masson studied a tumor } \\
\text { and found that its cells are similar to those found in the coccygeal gland or glomus } \\
\text { coccygeum and named the tumor glomus (latin for ball) tumor. He also gave the name } \\
\text { "Sucquet-Hoyer", based on the earlier report s of Sucquet in 1862 and Hoyer in 1877. }\end{array}$ \\
\hline
\end{tabular}

Table I. Selected Eponyms in the dermatology literature linked to the vascular tumors (continued)

\section{REFERENCES}

1. Al Aboud K, Al Hawsawi K, Ramesh V, Al Aboud D, Al Githami A: Eponyms in dermatology. Skinmed. 2004;3:11-2.

2. Schwartz RA: Dabska Tumor. E-medicine. http://emedicine. medscape.com/article/1112873-overview. Updated: Mar 9, 2012

3. Schwartz RA, Janniger EJ: On being a pathologist: Maria Dabskathe woman behind the eponym, a pioneer in pathology. Hum Pathol 2011;42:913-7.

4. Al Aboud K, Al Aboud A: Eponyms in the dermatology literature linked to the skin and soft tissue tumors. Our Dermatol Online. 2013;4:389-91.
5. Piette EW: Kimura disease. E-medicine.

http://emedicine.medscape.com/article/1098777-overview. Updated: Nov 7, 2012

6. Al Aboud K, Al Aboud A: Eponyms in dermatology literature linked to Canada. Our Dermatol Online. 2013;4:113-6.

7. Carroll RE, Berman AT: Glomus tumors of the hand: review of the literature and report on twenty-eight cases. J Bone Joint Surg Am. 1972;54:691-703.

Copyright by Khalid Al Aboud, et al. This is an open access article distributed under the terms of the Creative Commons Attribution License, which permits unrestricted use, distribution, and reproduction in any medium, provided the original author and source are credited. 